\title{
THE SYNTHESIS AND ANTIMICROBIAL ACTIVITY OF ISATIN-3-(4'-HYDROXY)BENZOYLHYDRAZONE
}

Sandra S. Konstantinovićc ${ }^{\star}$, Jelena Tomić1, Jasmina Savić ${ }^{2}$ Milica Zlatković1, Jasmina Jovanović Mirković ${ }^{3}$, Gordana V. Sredojević Dugalić ${ }^{4}$

${ }^{1}$ Faculty of Technology, University of Niš, Leskovac, Serbia

${ }^{2}$ Vinca Institute of Nuclear Science, University of Belgrade, Belgrade, Serbia

${ }^{3}$ High Medical School of Professional Studies, Ćuprija, Serbia

${ }^{4}$ Clinic of Pulmonary Diseases and TBC, Knez Selo, Clinical Center of Niš, Serbia

Isatin is an endogenous compound and acts as a important precursor for the synthesis of various pharmacologically active heterocyclic compounds. Isatin and its derivatives possess a different activity such as antimicrobial, antiviral, anti-inflammatory, anticonvulsive, antitumor, anti-HIV, etc. In the present work, isatin-3-(4-hydroxy)benzoylhydrazone was synthesized and identified by elemental microanalysis as well as FTIR, UVIVIS and MS methods. The compound was tested for antimicrobial activity against Staphylococcus aureus, Serratia marcescens, Pseudomonas aeruginosa, Klebsiella pneumoniae, Enterococcus faecalis and Candida albicans.
(ORIGINAL SCIENTIFIC PAPER) UDC 547.978

Keywords: Isatin, synthesis, spectroscopic analysis, antimicrobial activity

\section{Introduction}

Isatin and itş derivatives as biological and pharmaceutical active components are very important intermediates in different organic synthesis [1]. Isatin is an endogenous compound, which can be found in plants of the genus Isatis, in Calanthe discolor LINDL and Couroupita guianensis Aubl [2]. It is a consistent component of the secretion from the parotid gland of Bufo frogs and a metabolic derivative of adrenaline in humans [2].

Isatin is a building unit of various numbers of alkaloids, drugs, pesticides and dyes [3]. Isatin and its derivatives possess an antimicrobial, antiviral, anticonvulsive, antitumor, anti-HIV, anti-inflammatory and antimycobacterial activity [4].

Hydrazones also possess antibacterial, anticancer, tuberculostatic and fungicidal properties and have a wide application in medicine and pharmacy [5].

The present paper describes the synthesis and identification of isatin-3-(4'-hydroxy)benzoylhydrazone. The synthesized compound was tested for antibacterial activity against Staphylococcus aureus ATCC 6538, Enterococcus faecalis ATCC 29212, Pseudomonas aeruginosa ATCC 43895, Klebsiella pneumoniae ATTC 13883, Serratia marcescens ATCC 39006 and Candida albicans ATCC 10231 by the standard minimum inhibitory concentration (MIC) of a serial dilution test.

\section{Experimental}

Chemicals

All chemicals were of reagent grade and used without further purification. They were purchased from Sigma Aldrich (Munich, Germany).

\section{Instruments}

Carbon, hydrogen and nitrogen were determined by microanalysis using a Carlo Erba 1106 microanalyser. The melting point was determined in open capillary tubes in a Thomas-Hoover point apparatus and was uncorrected. The purity of the compound was obtained by TLC on silica gel using benzene:chloroform $=55: 45$, the compound being visualized by iodine vapors. The FTIR spectrum was recorded with a MichaelsonBomen MB-series spectrophotometer, using the $\mathrm{KBr}$ pellet $(1 \mathrm{mg} / 100 \mathrm{mg}$ ) technique. The UVIVIS spectrum was recorded on a Perkin-Elmer Lambda 15 UV/Vis spectrophotometer, using $10^{-5} \mathrm{~mol} \cdot \mathrm{dm}^{-3}$ solutions in $95 \%$ ethanol. MALDI-TOF mass spectrum was acquired on a Voyager Biospectrometry DE Pro Workstation (Perseptive Biosystems, Framingham, MA, USA). The instrument is equipped with a $20 \mathrm{~Hz} \mathrm{~N}$ laser emitting at $337 \mathrm{~nm}$. The spectrum was acquired without a low mass gate and the spectrum represents an average of at least 400 single laser shots. The spectrum was recorded from the methanolic solution of $1 \mu \mathrm{L}$, without a matrix.

\section{Methods}

Synthesis of isatin-3-(4 -hydroxy)benzoylhydrazone Isatin-3-(4'-hydroxy)benzoylhydrazone was prepared by the reaction of the equimolar amount of isatin (1.47g) and 4-hydroxybenzoylhydrazide (1.52g) in $95 \%$ ethanol

\footnotetext{
*Author address: Sandra Konstantinović, Faculty of Technology, University of Niš Bulevar oslobođenja 124, 16000 Leskovac, Serbia

E-mail:sakisandra12@yahoo.com

The manuscript received: April, 21, 2015.

Paper accepted: May, 15, 2015.
} 
following the standard procedure $[6,7]$. The mixture was refluxed at $50{ }^{\circ} \mathrm{C}$ for $60 \mathrm{~min}$. The product, precipitated as a yellow solid, was collected by filtration and washed with using a solvent.

\section{Antimicrobial activity}

The compound was evaluated for its in vitro antimicrobial activity against Gram-positive bacteria Staphylococcus aureus ATCC 25923 and Enterococcus faecalis ATCC 29212, Gram-negative bacteria Serratia marcescens ATCC 39006, Pseudomonas aeruginosa ATCC 43895, Klebsiella pneumoniae ATTC 13883, and the yeast Candida albicans ATTC 10231. The minimum inhibitory concentration (MIC) was assessed by the agar dilution method. The minimum inhibitory concentration (MIC) represents the concentration of antimicrobial at which there is a complete inhibition of the growth of organism. A series of different concentrations of the com- pound $(25 \mu \mathrm{g} / \mathrm{ml}, 50 \mu \mathrm{g} / \mathrm{ml}, 100 \mu \mathrm{g} / \mathrm{ml}, 200 \mu \mathrm{g} / \mathrm{ml}$ and $400 \mu \mathrm{g} / \mathrm{ml}$ ) with Mueller Hinton broth for bacteria and RPMI 1640 medium for the yeast was inoculated and incubated at $37^{\circ} \mathrm{C}$ for $24 \mathrm{~h}$ (bacteria) and $48-72 \mathrm{~h}$ for the yeast [6-9].

\section{Results and discussion}

Isatin-3-(4'-hydroxy)benzoylhydrazone was synthesized by using the carbonyl-amine condensation reaction of isatin and 4-hydroxybenzoylhydrazide (Figure 1). Although the primary amines are suitable nucleophilic, the reaction required an acid catalyst to activate a carbonyl group, speed reaction and to allow the water elimination. The $\mathrm{C}-3$ position in isatin is very susceptible to the nucleophilic attack, while C-2 reacts with nucleophiles only under specific conditions due to a negative inductive effect of the amido group [2].<smiles>NNC(=O)c1ccc(O)cc1</smiles>

Figure 1.Synthesis of isatin-3-(4`-hydroxy)benzoylhydrazone using the carbonyl-amine condensation reaction

Table 1. Physico-chemical characteristics of isatin-3-(4-hydroxy)benzoylhydrazone

\begin{tabular}{llllllll}
\hline \multicolumn{1}{c}{ Compound } & Color & $\begin{array}{c}\text { Melting } \\
\text { Point } \\
\left({ }^{\circ} \mathrm{C}\right)\end{array}$ & $\mathbf{C}$ & $\frac{\text { Analysis }^{\mathrm{a}}(\%)}{\mathbf{H}}$ & $\mathbf{N}$ & Solubility \\
\hline $\begin{array}{l}\text { Isatin-3-(4- } \\
\text { hydroxy)benzoylhydrazone }\end{array}$ & Yellow & 245 & $\begin{array}{c}64.02 \\
(64.06)\end{array}$ & $\begin{array}{c}3.96 \\
(3.94)\end{array}$ & $\begin{array}{c}14.99 \\
(14.94)\end{array}$ & $\begin{array}{l}\text { Ethanol, } \\
\text { Methanol, } \\
\text { DMF, DMSO }\end{array}$ \\
\hline a-Found (Calculated) & & & & & & &
\end{tabular}

The yield of the synthesized compound is significant (94.30\%). The experimental and calculated values for the elemental analysis are in a good accordance, which confirms the suggested molecular formula $\mathrm{C}_{15} \mathrm{H}_{11} \mathrm{~N}_{3} \mathrm{O}_{3}$ of isatin-3-(4’-hydroxy)benzoylhydrazone (Table 1).

\section{UVNIS spectral analysis of}

isatin-3-(4'-hydroxy)benzoylhydrazone

The UV/VIS spectra of isatin, 4-hydroxybenzoylhydrazide and isatin-3-(4'-hydroxy)benzoylhydrazone were recorded in the solution of $95 \%$ ethanol (Figure 2). The numerical data are given in Table 2. Comparing to electronic spectra of started components, the spectrum of isatin-3-(4'-hydroxy)benzoylhydrazone shows a new band at $\lambda \max =342 \mathrm{~nm}$. This is a characteristic absorp- tion band for the azomethine $(\mathrm{HC}=\mathrm{N})$ group and also the confirmation of the isatin derivative formation. 


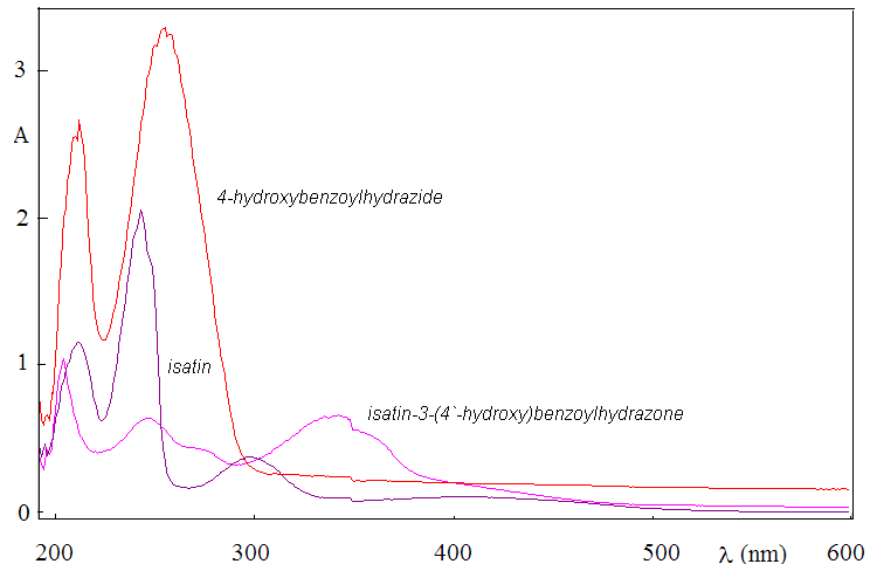

Figure 2. UV/VIS spectra of isatin, 4-hydroxybenzoylhydrazide and isatin-3-(4 hydroxy)benzoylhydrazone

Table 2. UVIVIS spectral data of isatin, 4-hydroxybenzoylhydrazide and isatin3-(4'-hydroxy)benzoylhydrazone

\begin{tabular}{ccc}
\hline Compound & $\lambda(\mathrm{nm}) / \varepsilon \cdot 10^{3}\left(\mathrm{~mol}^{-1} \cdot \mathrm{dm}^{-3} \cdot \mathrm{cm}^{-1}\right)$ & Band assignation \\
\hline Isatin & $212.0 / 1.1575$ & $\pi \rightarrow \pi^{*}$ \\
& $243.0 / 2.0561$ & $\pi \rightarrow \pi^{*}$ \\
& $300.0 / 0.3758$ & $n \rightarrow \pi^{*}$ \\
4-hydroxybenzoylhydrazide & $212.0 / 2.6675$ & $\pi \rightarrow \pi^{*}$ \\
& $255.0 / 3.2910$ & $\pi \rightarrow \pi^{*}$ \\
isatin-3-(4 -hydroxy)benzoylhydrazone & $258.0 / 3.2487$ & $\pi \rightarrow \pi^{*}$ \\
& $204.0 / 1.0437$ & $\pi \rightarrow \pi^{*}$ \\
& $246.0 / 0.6390$ & $\pi \rightarrow \pi^{*}$ \\
\hline
\end{tabular}

FTIR spectral analysis of

isatin-3-(4'-hydroxy)benzoylhydrazone

The main IR spectral bands and their numerical data are given in Figure 3 and Table 3. Comparing to spectra of isatin and 4-hydroxybenzoylhydrazide, the spectrum of isatin-3-(4-hydroxy)benzoylhydrazone contains a band at $1610 \mathrm{~cm}^{-1}$, due to a newly formed $\mathrm{v}(\mathrm{C}=\mathrm{N})$ stretching vibration. The spectrum of 4-hydroxybenzoylhydrazide contains symmetrical and asymmetrical $\mathrm{NH}_{2}$ stretching bands at $3316 \mathrm{~cm}^{-1}$ and $3274 \mathrm{~cm}^{-1}$, which cannot be found in the spectrum of isatin-3-(4'-hydroxy)benzoylhydrazone. The position of other bands are slightly batochromic shifted due to extended conjugation within isatin-3-(4`-hydroxy)benzoylhydrazone

MS spectral analysis of isatin-3-(4'-hydroxy)benzoylhydrazone

Mass spectrum of the synthesized compoundis given in Figure 4. The spectrum of isatin-3-(4'-hydroxy)benzoylhydrazone contains the characteristic molecular ion $\left(\mathrm{M}^{+}\right)$at $\mathrm{m} / \mathrm{z}=281$. The position of this peak is in accordance with the molecular mass of the compound with molecular formula $\mathrm{C}_{15} \mathrm{H}_{11} \mathrm{O}_{3} \mathrm{~N}_{3}$. It also followed the "nitrogen rule", by which the odd number of nitrogen means the odd molecular mass of the molecule. The spectrum con- tains a peak near a molecular one which is of low intensity and belongs to $\mathrm{M}+1$ ion. This is also a characteristic of the compounds with nitrogen atoms, i.e. isotopes $u$ ${ }^{14} \mathrm{~N}$ and ${ }^{15} \mathrm{~N}$. The spectrum contains high-intensity peaks at $\mathrm{m} / \mathrm{z}=149\left[\mathrm{C}_{8} \mathrm{H}_{5} \mathrm{~N}_{3} \mathrm{O}\right]^{+}$and $\mathrm{m} / \mathrm{z}=121\left[\mathrm{C}_{7} \mathrm{H}_{5} \mathrm{NO}\right]^{+}$which belong to fragmentation ions.

Antimicrobial activity

Experimental results of the antimicrobial activity are given in Table 4. MIC values show that isatin-3-(4'-hydroxy)benzoylhydrazone possesses a different activity against the tested microorganisms.

The best results are shown against the Gram-positive bacteria Enterococcus faecalis and yeast Candida albicans in the concentration range of $25-50 \mu \mathrm{g}-\mathrm{cm}^{-3}$. Isatin-3-(4'-hydroxy)benzoylhydrazone shows a medium activity against Gram-negative bacteria Klebsiella pneumoniae, Serratia marcescens i Pseudomonas aeruginosain the concentration range of $50-100 \mu \mathrm{g}-\mathrm{cm}^{-3}$, while the lowest activity is achieved against the Gram-positive bacteria Staphylococcus aureusin the concentration of $<100 \mu \mathrm{g}-\mathrm{cm}^{-3}$. 


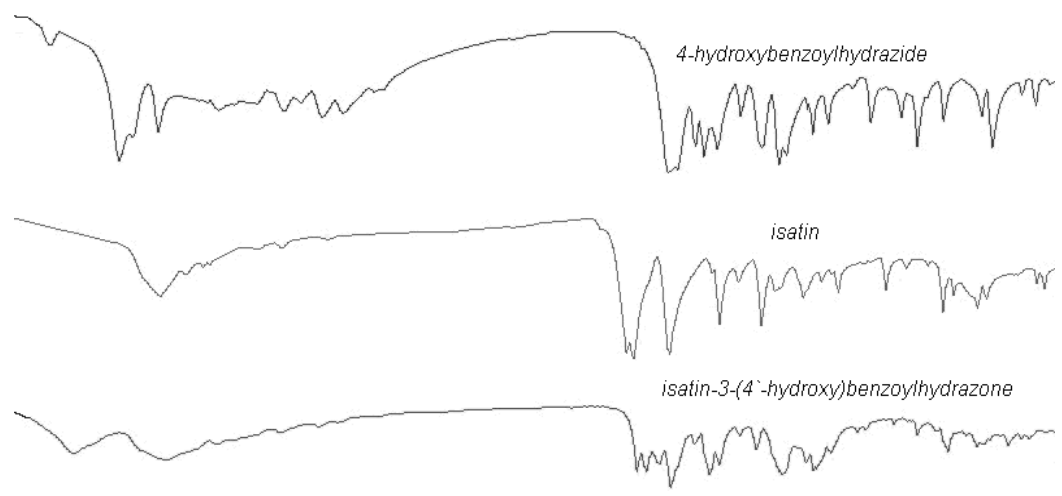

Figure 3. FTIR spectrum of isatin, 4-hydroxybenzoylhydrazide and isatin-3-(4'-hydroxy)benzoylhydrazone

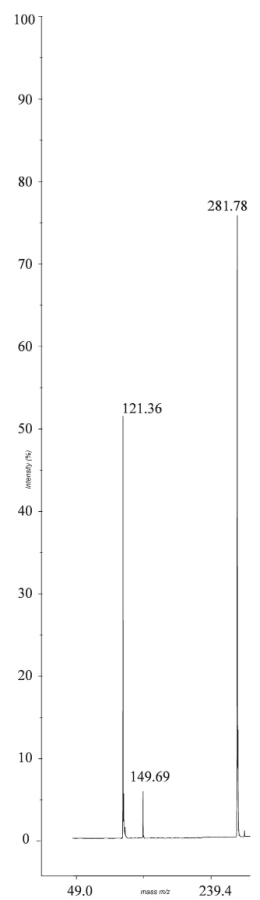

Figure 4. MS spectrum of isatin-3-(4`hydroxy) benzoylhydrazone

Table 3. FTIR spectral data of isatin, 4-hydroxybenzoylhydrazide and isatin-3-(4'-hydroxy)benzoylhydrazone

\begin{tabular}{cccc}
\hline $\begin{array}{c}\text { Band assignation } \\
\left(\mathrm{cm}^{-1}\right)\end{array}$ & Isatin & 4-hydroxybenzoylhydrazide & $\begin{array}{c}\text { isatin-3-(4- } \\
\text { hydroxy)benzoylhydrazone }\end{array}$ \\
\hline$v(\mathrm{OH})$ & - & 3560 & 3450 \\
$v \mathrm{~N}\left(\mathrm{NH}_{2}\right)+$ vas & - & 3316,3274 & - \\
$\left(\mathrm{NH}_{2}\right)$ & 3189 & 3196 & 3251,3176 \\
$v(\mathrm{NH})$ & 1740,1720 & - & 1715,1686 \\
$v(\mathrm{C}=\mathrm{O})$ & - & 1249 & 1610 \\
$v(\mathrm{C}=\mathrm{N})$ & - & 1590 & 1265 \\
$\delta(\mathrm{OH})$ & - & 1510 & - \\
$\delta(\mathrm{NH})_{2}$ & 1460 & 1173 & 1537,1491 \\
$\delta(\mathrm{NH})$ & 1201 & & 1192 \\
$v(\mathrm{C}-\mathrm{O})$ & & &
\end{tabular}

Table 4. MIC values ( $\left.\mu \mathrm{g}-\mathrm{cm}^{-3}\right)$ of isatin-3-(4`-hydroxy)benzoylhydrazone

\begin{tabular}{ccccccc}
\hline Microorganism & \multicolumn{5}{c}{ Concentration of } & isatin-3-(4-hydroxy)benzoylhydrazone $\left(\mu \mathrm{g} \cdot \mathrm{cm}^{-3}\right)$ \\
& 25 & 50 & - & - & +200 & 400 \\
\hline Staphylococcus aureus & - & - & + & + & + \\
Klebsiella pneumoniae & - & - & + & + & + \\
Serratia marcescens & - & - & + & + & + \\
Pseudomonas aeruginosa & - & - & + & + & + \\
Enterococcus faecalis & - & + & + & + & + \\
Candida albicans & - & + & & & + \\
\hline
\end{tabular}

$(+)$ active

(-) neactive 


\section{Conclusion}

The synthesis of isatin-3-(4 -hydroxy)benzoylhydrazone was done by using the carbonyl-amine condensation reaction of isatin and 4-hydroxybenzoylhydrazide in $95 \%$ ethanol. The structure and molecular formula $\mathrm{C}_{15} \mathrm{H}_{11} \mathrm{O}_{3} \mathrm{~N}_{3}$ of the synthesized compound was established by the elemental microanalysis as well as FTIR, UV/VIS and MS methods. The compound shows a different antimicrobial activity against Staphylococcus aureus, Serratia marcescens, Pseudomonas aeruginosa, Klebsiella pneumoniae, Enterococcus faecalis and Candida albicans. The best results were shown against the Gram-positive bacteria Enterococcus faecalis and yeast Candida albicans in the concentration range of $25-50 \mu \mathrm{g}-\mathrm{cm}^{-3}$.

\section{Aknowledgments}

This work has been funded by the Ministry of Education, Science and Technological Development of the Republic of Serbia (Project III 45001).

\section{References}

[1] P. Ramu, T.A.A.Prasad, S.M., Vithiyac, S. A.Antony, Synthesis, characterization and biological activity of novel spiroheterocycles from isatin derivatives, Der Pharma Chemica, 6(2014) 30-36.
[2] J.F.M. da Silva, S.J. Garden, A. C Pinto, The Chemistry of Isatins: a Review from 1975 to 1999 , Journal of the Brazilian Chemical Society, 12 (2001) 273-324.

[3] N.Lashgari, G. M. Ziarani, Synthesis of heterocyclic compounds based on isatin through 1, 3-dipolar cycloaddition reactions, ARKIVOC i (2012) 277-320.

[4] G. Mathur, S. Nain, Recent Advancement in Synthesis of Isatin as Anticonvulsant Agents: A Review, Medicinal Chemistry, 4 (2014) 417-427.

[5] S. Konstantinović, B. Radovanović, Ž. Cakić, V. Vasić, Synthesis and characterization of $\mathrm{Co}(\mathrm{II}), \mathrm{Ni}(\mathrm{II}), \mathrm{Cu}(\mathrm{II})$ and Zn(II) complexes with 3-salicylidenehydrazono2-indolinone, Journal of Serbian Chemical Society, 68(2003)641-647.

[6] S. Konstantinović, B. Konstantinović, J. Jovanović,Synthesis and structure of vanillin azomethines, Chemical Industry \& Chemical Engineering Quarterly, 15 (2009) 279-281.

[7] S. Konstantinović, A. Kapor, B. Radovanović, A. Deak, Synthesis, X-ray and antimicrobial activity of isatin3-phenylhydrazone, Chemical Industry \& Chemical Engineering Quarterly, 14 (2008) 27-34.

[8] NCCLS Approval Standard Document M7-A5, National Committee for Clinical Laboratory Standards, Villanova, $\mathrm{Pa}$, USA, 2000

[9] Reference method for broth dilution antifungal susceptibility testing for yeasts; approved standard Document M27-A, National Committee for Clinical Laboratory Standards, Villanova,PA, USA, 17(1997) 1-29.

Izvod

\section{SINTEZA I ANTIMIKROBNA AKTIVNOST IZATIN-3-(4'-HIDROKSI)BENZOILHIDRAZONA}

Sandra S. Konstantinović ${ }^{1^{*}}$, Jelena Tomić1, Jasmina Savić2 ${ }^{2}$ Milica Zlatković1, Jasmina Jovanović Mirković ${ }^{3}$, Gordana V. Sredojević Dugalić ${ }^{4}$

\footnotetext{
${ }^{1}$ Tehnološki fakultet, Univerzitet u Nišu, Leskovac, Srbija

2 INN Vinča, Univerzitet u Beogradu, Beograd, Srbija

${ }^{3}$ Visoka medicinska škola strukovnih studija, Ćuprija, Srbija

${ }^{4}$ Klinika za plućne bolesti, Knez Selo, Klinički centar Niš, Srbija
}

Izatin je endogeno heterociklično jedinjenje koje predstavlja veoma važan prekursor u sintezi farmaceutski aktivnih komponenti. Izatin i njegovi derivati poseduju različitu biološku aktivnost, kao što je antimikrobna, antiviralna, antiinflamatorna, antikonvulzivna, antitumorna, anti-HIV, itd. U ovom radu je izvršena sinteza izatin3-(4`hidroksi)benzoilhidrazona i jedinjenje je identifikovano pomoću elementarne mikroanalize, FTIR, UVIVIS i MS metode. Sintetisanom derivatu izatina je određena antimikrobna aktivnost dilucionom metodom, odnosno određivanjem MIC vrednosti u odnosu na mikroorganizme Staphylococcus aureus, Serratia marcescens, Pseudomonas aeruginosa, Klebsiella pneumoniae, Enterococcus faecalis i Candida albicans. Najbolji rezultati su postignuti u odnosu na Grampozitivnu bakteriju Enterococcus faecalis i kvasac Candida albicans u koncentraciji $25-50 \mu \mathrm{g}-\mathrm{cm}^{-3}$.
(ORIGINALNI NAUČNI RAD) UDK 547.978

Ključne riječi: Izatin, sineza, spektroskopska analiza, antimikrobna aktivnost 